\title{
Effect of starter nitrogen on yield and yield components of chickpea (Cicer arietinum L.) at Dokri, Larkana
}

Javed Shabbir Dar ${ }^{1}$, Pushpa ${ }^{1}$, Muhammad Ishaq Asif Rehmani², Zulfiqar Ali Abbassi ${ }^{1}$ and Abdul Ghafoor Magsi ${ }^{1}$

1. Department of Agronomy, SZABAC Dokri, Larkana-Pakistan

2. Department of Agronomy, Ghazi University, D. G. Khan-Pakistan

*Corresponding author's email: dr.rehmani.mia@ hotmail.com

Citation

Javed Shabbir Dar, Pushpa, Muhammad Ishaq Asif Rehmani, Zulfiqar Ali Abbassi and Abdul Ghafoor Magsi. Effect of starter nitrogen on yield and yield components of chickpea (Cicer arietinum L.) at Dokri, Larkana. Pure and Applied Biology. Vol. 5, Issue 4, pp1296-1303. http://dx.doi.org/10.19045/bspab.2016.50155

Received: $29 / 07 / 2016$

Revised: 27/10/2016

Accepted: 12/11/2016

Online First: 02/12/2016

\section{Abstract}

Nitrogen (N) fixing capacity of legumes varies greatly among species and due to soil conditions. Poor soil conditions may cause yield reduction of chickpea as a result of limited biological $\mathrm{N}$ fixation. A field experiment was conducted to evaluate impact of starter $\mathrm{N}$ levels on growth and yield of chickpea. Study was planned with four levels of starter $\mathrm{N}\left(0,15,30\right.$ and $\left.45 \mathrm{~kg} \mathrm{~N} \mathrm{ha}^{-1}\right)$ with three replications at Research Area, Agronomy Department, Rice Research Institute, Dokri during 2014-15 and 2015-16. The variety DG-92 was used in the experiment. Results show that plant height, number of pods per plant, seed index and seed yield were significantly improved with the various levels of starter N. The results of correlation coefficient in 2014-2015 and 20152016 years were positive and significant correlations of seed yield with majority traits.

Keywords: Chickpea; Legume; Seed yield; Nitrogen fertilizer; Yield components

\section{Introduction}

In Pakistan chickpea (Cicer arietinum L.) is an important food legume crop grown in rabi (winter) season. It is an economical source of proteins, carbohydrates, oil, minerals and vitamins, therefore serve as integral component of diet, especially for poor $[1,2]$. It is also used in preparation of variety of condiments, soups, snacks and sweets [3]. Chickpea is adaptable to diverse agro-climatic conditions and grown in the subtropics to arid and semi-arid regions [4]. It is predominantly grown in cool, dry periods on receding soil moisture, however it is sensitive to alkalinity, salinity and water logging [5]. Chickpea is generally cultivated as barani or rainfed crop. Being a multipurpose crop; it is used as food, feed and industrial purpose, its demand is continuously increasing [6]. Although origin of chickpea is controversial, however, it is thought to be originated from western Asia, from where it spread to Europe and in more recently introduced in tropical Africa, Australia and central and southern America [7]. South Asian countries produce more than two-third of global chickpea production. In addition to South Asian subcontinent it is also grown in West Asia, Australia North and East Africa, and North 
America [8]. Botanically chickpea is of two types, desi (microsperma) mainly grown for its nutritious seeds, and kabuli (macrosperma) grown to provide salad and vegetable mixes [9]. In Pakistan it covers an area of around 9.6 million hectares and during 2014-2015; the total annual production of chickpea is 4.84 million tones, with an average yield of $487 \mathrm{~kg} \mathrm{ha}^{-1}$, against the production of 3.99 million tons during 2013-14. Showing 21.3\% increase in yield due [10].

In Pakistan average yield of chickpea is lower than its yield potential and also lower than neighbor India [11], mainly due to unfavorable growth conditions, its management and poor breeding program. Average yield can be increased through integrated soil and crop management practices. Increasing population, erratic yield pattern of main crops and increased trade of chickpea resulted in increased demand of alternate or marginal crops like chickpea [12]. Like other legumes it can be a very useful legume crop for incorporation into short-term rotation and for fixation of $\mathrm{N}$ in soil and its fertility [13, 14]. Pakistani soils are deficient of $\mathrm{N}$ in general, low organic matter contents in soil is one of major causes of deficiency of the nutrients [15]. Deficiency of $\mathrm{N}$ is one the yield limiting factors for major agricultural crops $[16,17]$. Being integral part of protein, chlorophyll, nucleic acid and protoplasm, and its involvement in photosynthetic activity, amino acid and protein synthesis, cell division and enlargement, leaf production and extension, $\mathrm{N}$ has a vital role in the crop performance and production [18, 19]. It also improves the protein contents of food grains and fodder quality [20]. Therefore ample supply of $\mathrm{N}$ is imperative to attain higher crop yields. Deficiency of $\mathrm{N}$ in agricultural crops results in reduced crop growth rate, chlorosis, early leaf senescence and ultimate yield losses [21].
Maintenance of soil fertility and application of sufficient and balanced nutrient is vital for increasing crop yield, especially in nutrient deficient soils [22-24]. Legumes are restorative crops and capable to produce major component of their $\mathrm{N}$ requirement through biological $\mathrm{N}$ fixation [14]. Legume crops greatly vary in their capacity to fix atmospheric N [25]. Association of legumeRhizobium is highly dependent on various abiotic factors including spatiotemporal variations, management practices, cropping system, agro-climatic and soil characteristics $[24,26]$. Symbiotic association between chickpea and Mesorhizobium ciceri fix atmospheric $\mathrm{N}$ and supply significant proportion of plant $\mathrm{N}$ requirement [26], which may not necessarily added to the soil. Modest level of $\mathrm{N}$ fixation in chickpea (both desi and kabuli) and common bean can result in limited advantage of $\mathrm{N}$ addition in soil rather can cause soil $\mathrm{N}$ deficit. Fertilization of $\mathrm{N}$ was strongly correlated with the increase in yield [27]. Inadequate biological $\mathrm{N}$ fixation in poor soil conditions can potentially reduce yield in chickpea and other legume crops [25]. Reservoirs of $\mathrm{N}$ in seed and soil can sufficiently provide $\mathrm{N}$ requirements till seedling stage of chickpea, whereas biological $\mathrm{N}$ fixation can supplement $\mathrm{N}$ for the subsequent plant growth. Therefore, symptoms of $\mathrm{N}$ deficiency are rarely shown by chickpea. However, limited biological $\mathrm{N}$ fixation and deficiency of $\mathrm{N}$ in soil can induce $\mathrm{N}$ deficiency in legume plants, which happened after expiry of seed $\mathrm{N}$ and before the effective nodule formation [28]. To alleviate $\mathrm{N}$ deficiency and encourage good initial growth of legume plants starter dose of $\mathrm{N}$ is required, especially in soils with low nutrient holding capacity e.g., sandy loam soils [28, 29]. It is well known that higher levels of $\mathrm{N}$ can negatively influence nodulation and biological $\mathrm{N}$ fixation. Therefore optimum $\mathrm{N}$ fertilization level is 
important to maximize chickpea yield and profitability. The present study was performed to determine growth and yield of chickpea crop to varying levels of starter $\mathrm{N}$ fertilizer under agro-climatic conditions of Dokri, Sindh, Pakistan.

\section{Materials and methods}

Field experiment was performed at the Research Area of Agronomy Section, Rice Research Institute Dokri, Larkana, Sindh, Pakistan, during 2014-15 and 2015-16 using. Chickpea cultivar DG-92 was exposed to four levels of Nitrogen (N) including $\mathrm{N} 0=($ Control $) 0 \mathrm{~kg} \mathrm{~N}^{-1}, \mathrm{~N} 1=$ $15 \mathrm{~kg} \mathrm{~N} \mathrm{ha}^{-1}, \mathrm{~N} 2=30 \mathrm{~kg} \mathrm{~N} \mathrm{ha}^{-1}$ and N3 $=45$ $\mathrm{kg} \mathrm{N} \mathrm{ha}{ }^{-1}$. The research was arranged in randomized complete block design (RCBD) with three replications. Chickpea plants were sown on experimental plot of net area of $7.2 \mathrm{~m} 2(\mathrm{~L} \times \mathrm{W}=4 \times 1.8 \mathrm{~m})$ with $\mathrm{P} \times \mathrm{P}$ and $\mathrm{R} \times \mathrm{R}$ distances of $15 \mathrm{~cm}$ and, $30 \mathrm{~cm}$, with six rows and 160 plants per plot. Soil of experimental site was $\mathrm{N}$ deficient and high (8.3) $\mathrm{pH}$. Under different $\mathrm{N}$ treatment complete $\mathrm{N}$, as urea, was applied as single dose at the time of seed bed preparation. Standard and uniform plant protection measures and agronomic practices were performed throughout the growing season to avoid any unwanted stress, except $\mathrm{N}$ levels. The observations were made based on randomly selected and averages of five plants were used each experimental unit, which were further averaged for treatments means used for statistical analysis. Data on various traits including plant height, seeds per pod, branches per plant, pods per plant, seed index and seed yield were recorded.

Table 1. Plant growth and yield as influenced by different nitrogen levels by DG-92 during 2014-15

\begin{tabular}{|c|c|c|c|c|c|c|}
\hline & $\begin{array}{l}\text { Plant } \\
\text { Height }(\mathrm{cm})\end{array}$ & $\begin{array}{l}\text { No. of seeds } \\
\text { per pod }\end{array}$ & $\begin{array}{l}\text { No. of pods } \\
\text { per plant }\end{array}$ & $\begin{array}{l}\text { No. of branches } \\
\text { per plant }\end{array}$ & $\begin{array}{l}\text { 100-seed } \\
\text { weight (g) }\end{array}$ & $\begin{array}{l}\text { Seed yield } \\
\left(\mathrm{kg} \mathrm{ha}^{-1}\right)\end{array}$ \\
\hline $\begin{array}{l}N_{0}=\text { control } \\
\left(0 \mathrm{~kg} \mathrm{ha}^{-1}\right)\end{array}$ & $24.4 \mathrm{c}$ & 1.0 & $25.2 \mathrm{c}$ & 4.4 & $21.5 \mathrm{c}$ & $1058 \mathrm{c}$ \\
\hline$N_{1}\left(15\right.$ kg ha $\left.^{-1}\right)$ & $26.5 \mathrm{c}$ & 1.4 & $30.6 \mathrm{~b}$ & 5.6 & $24.3 \mathrm{~b}$ & $1409 \mathrm{~b}$ \\
\hline $\mathrm{N}_{2}\left(30 \mathrm{~kg} \mathrm{ha}^{-1}\right)$ & $30.4 \mathrm{~b}$ & 2.0 & $38.4 \mathrm{a}$ & 6.4 & $27.4 \mathrm{a}$ & $1962 \mathrm{a}$ \\
\hline$N_{3}\left(45 \mathrm{~kg} \mathrm{ha}^{-1}\right)$ & $34.3 \mathrm{a}$ & 1.8 & $38.0 \mathrm{a}$ & 6.6 & $27.1 \mathrm{a}$ & $1911 \mathrm{a}$ \\
\hline LSD Value & 3.01 & Ns & 4.3 & Ns & 2.1 & 194.23 \\
\hline
\end{tabular}

Plant height was recorded from surface of ground to top tip of leaves. Number branches per plant, pods per plant and seeds per pod were recorded by counting branches, pods and seeds of each plant separately and then averaged from each replication. After separating yield, five samples of 100 seeds were picked at random from each replication, and then weight was recorded. Twenty plants were selected from each experimental plot. Calculate the value by unit formulae and then converted to $\mathrm{kg}$ $\mathrm{ha}^{-1}$ (Calculated the seed yield of 20 plants and then divided by 20 . The obtained value was multiplied with standard plant population. Calculate the data and then averaged from each replication.

The data collected were analyzed with one way ANOVA by MSTATC. For treatment mean discrimination LSD test was applied at 0.05 probability level [30].

\section{Results}

\section{Effect of nitrogen on plant height}

Data presented in Table 1 and 2 showed that $\mathrm{N}$ play a significant role in defining plant height during both experimental years. Maximum plant height of chickpea was recorded at the treatment $\mathrm{N} 3(34.4 \mathrm{~cm}$ and $35.1 \mathrm{~cm})$, while as compared to treatment N0 $(24.4 \mathrm{~cm}$ and $25.5 \mathrm{~cm})$. In control treatment (N0) chickpea plants were $29 \%$ and $27 \%$ shorter plants than plants produced in treatment N3 during 2014-15 and 2015-16 respectively. These findings are in line the results of Namvar et al., 2011 who also reported that plant height of chickpea increase with increasing rate of $\mathrm{N}$ [31]. 
Table 2. Plant growth and yield as influenced by different nitrogen levels by DG-92 during 2015-16

\begin{tabular}{|l|l|l|l|l|l|l|}
\hline & $\begin{array}{l}\text { Plant Height } \\
(\mathbf{c m})\end{array}$ & $\begin{array}{l}\text { No. of } \\
\text { per pod }\end{array}$ & $\begin{array}{l}\text { No. of pods } \\
\text { per plant }\end{array}$ & $\begin{array}{l}\text { No. of branches } \\
\text { per plant }\end{array}$ & $\begin{array}{l}\text { 100-seed } \\
\text { weight }(\mathbf{g})\end{array}$ & $\begin{array}{l}\text { Seed yield } \\
\left(\mathbf{k g ~ h a}^{-1}\right)\end{array}$ \\
\hline $\begin{array}{l}\mathbf{N}_{\mathbf{0}}=\text { control }_{\mathbf{0}} \\
\left(\mathbf{0} \mathbf{~ k g ~ h a}^{-1}\right)\end{array}$ & $25.5 \mathrm{~b}$ & 1.2 & $26.4 \mathrm{c}$ & 4.2 & $23.2 \mathrm{c}$ & $1105 \mathrm{c}$ \\
\hline $\mathbf{N}_{\mathbf{1}}\left(\mathbf{1 5} \mathbf{~ k g ~ h a}^{-\mathbf{1}}\right)$ & $28.1 \mathrm{~b}$ & 1.4 & $31.2 \mathrm{~b}$ & 5.4 & $25.5 \mathrm{bc}$ & $1460 \mathrm{~b}$ \\
\hline $\mathbf{N}_{\mathbf{2}}\left(\mathbf{3 0} \mathbf{~ k g ~ h a}^{-1}\right)$ & $32.6 \mathrm{a}$ & 2.0 & $39.6 \mathrm{a}$ & 7.2 & $28.8 \mathrm{a}$ & $2023 \mathrm{a}$ \\
\hline $\mathbf{N}_{\mathbf{3}}\left(\mathbf{4 5} \mathbf{~ k g ~ h a}^{-1}\right)$ & $35.1 \mathrm{a}$ & 1.8 & $38.4 \mathrm{a}$ & 6.8 & $27.8 \mathrm{ab}$ & $1940 \mathrm{a}$ \\
\hline LSD Value & 3.1 & $\mathrm{Ns}$ & 4.4 & $\mathrm{Ns}$ & 2.2 & 203.18 \\
\hline
\end{tabular}

\section{Number of branches per plant}

Total branches per plant is an important yield attribute in legumes, which increased significantly with increasing level of $\mathrm{N}$ fertilizer, though this increasing trend could not reach significant level.

\section{Number of pods per plant}

Different treatments of starter $\mathrm{N}$ application significantly influenced total pods per plant. Maximum number of pods per plant were recorded in N2 (38.4 and 39.6) and N3 (38 and 38.4) during 2014-15 and 2015-2016 respectively, which were approximately $33 \%$ higher than control. There is no significant difference in between N2 and N3. Lowest no of pods per plant were recorded from control treatment N0 (25.2 and 26.4) during 2014-15 and 2015-2016 respectively.

\section{Number of seeds per pod}

Data presented in Tables 1 and 2 showed no significant influence of $\mathrm{N}$ application on number of seeds per pod of chickpea, however maximum number of seeds per pod were produced under treatment N2 during both experimental years.

\section{0-Seed weight}

Seed weight is one of the important components of yield parameter. In this experiment 100-seed index showed the significant difference among all the treatments. Maximum seed index was recorded in $\mathrm{N} 2(27.4 \mathrm{~g}$ and $28.8 \mathrm{~g})$ and $\mathrm{N} 3$ (27.1g and 27.8g) during 2014-15 and 201516 respectively. On overall average basis N2 produce $21 \%$ more seed index as compare to control treatment. Lowest seed index was reported by $\mathrm{N} 0(21.5 \mathrm{~g}$ and $23.2 \mathrm{~g}$ ) during 2014-15 and 2015-16 respectively.

\section{Seed yield}

Seed yield is to measure the combined effect of all the individual yield attributes, which may differently influenced by agronomic practices, adaphic and environmental factors. The data presented in Table 1 (201415) and Table 2 (2015-2016) highlighted that seed yield was significantly influenced by the starter $\mathrm{N}$ treatments. All the treatments enhanced gram seed yield significantly over control (N0). Highest seed yield was recorded in N2 (4708 and 4856) and the lowest was recorded in control treatment (2539 and 2651) during 2014-15 and 2015-16 respectively.

\section{Correlation}

Plant height showed significantly positive correlation with no. of branches per plant and no of pods per plant (Table 3). No of pods per plant also show the positive correlation with no of branches per plant and seed index. Seed yield is correlated with growth and yield parameters. It show positive correlation with plant height, no. of pods per plant, no of branches per plant and seed index during both the year. 
Table 3. Simple correlation coefficient values between some developmental parameters of chickpea during 2014-15 and 2015-16

\begin{tabular}{|l|l|l|}
\hline & $\mathbf{2 0 1 3 - 1 4}$ & $\mathbf{2 0 1 4 - 1 5}$ \\
\hline Plant height vs. no. of branches per plant & $0.826^{* *}$ & $0.839^{* *}$ \\
\hline Plant height vs. pods per plant & $0.761^{* *}$ & $0.798^{* *}$ \\
\hline pods per plant vs branches per plant & $0.591^{*}$ & $0.599^{*}$ \\
\hline pods per plant vs 100-seed weight & $0.791^{* *}$ & $0.837^{* *}$ \\
\hline Seed yield vs pods per plant & $0.963^{* *}$ & $0.977^{* *}$ \\
\hline Seed yield vs Branches per plant & $0.691^{* *}$ & $0.709^{* *}$ \\
\hline Seed yield vs plant height & $0.869^{* *}$ & $0.876^{* *}$ \\
\hline Seed yield vs 100-seed weight & $0.739^{* *}$ & $0.757^{* *}$ \\
\hline
\end{tabular}

\section{Discussions}

The increase in growth and yield traits of chickpea due to the application of nutrients might be due to higher availability of $\mathrm{N}$ applied and nodule formation to plants, besides increased water holding capacity and other physico-chemical and biological properties of soil. Adequate supply of $\mathrm{N}$ results towering crop yields and maintain soil health for longer period. Caliskan et al. (2008) and Namvar et al. 2011 also found that plant height increased with increasing level of $\mathrm{N}$ levels, in soybean (Turkey) and chickpea (Iran) [18, 31]. Similar increasing trend in chickpea branching with increasing $\mathrm{N}$ levels were reported earlier [31]. However they used much higher rates of $\mathrm{N}$ fertilizer i.e., $0,50,75$ and $100 \mathrm{~kg} \mathrm{ha}^{-1}$. Due to higher levels of $\mathrm{N}$ fertilizer they achieved almost double branching in treatment with $100 \mathrm{~kg}$ $\mathrm{N}$ ha $^{-1}$ as compared to control. $\mathrm{N}$ is structural component of protein, nucleic acids and chlorophyll, therefore its supply to the plant will promote amino acid, protein, protoplasm and chlorophyll formation and ultimately promote cell division and size, photosynthetic activity, leaf area and growth rate $[18,24,31]$. Increasing level of $\mathrm{N}$ fertilizer results in higher number of pods per plant, however to a certain limit, beyond that level no further increase was observed $[18,31]$. Increased yield of chickpea with $\mathrm{N}$ application also reported from Sudan and India which can be attributed to increase photosynthetic reserves and fast development of leaf area at early growth stages [28, 32, 33]. Contrary to our results Amany et al., 2007 and Namvar et al., 2011 reported significant increase branching of chickpea in response to $\mathrm{N}$ fertilizer application [31, 34], however they used much higher amounts of $\mathrm{N}$ fertilizer. Similar to our findings Amany, (2007) also reported significant increase in number of pods per plant. However in our study seeds per pod remained statistically similar under different $\mathrm{N}$ levels [34]. In this two-year field study $\mathrm{N}$ application influenced growth and yield attributes of chickpea, which were promoted with higher level of $\mathrm{N}$. In addition to the nutritive advantage, $\mathrm{N}$ application also enhances water use efficiency and improve chickpea yield [35]. Higher seed yield of chickpea with the application of starter $\mathrm{N}$ fertilizer application was mainly due to better plant growth and yield attributes such as pods plant, seeds per pod and 100-seed weight $[36,37]$.

\section{Conclusion}

Increasing nitrogen application were seen to result in significant increase in plant height, number of pods per plant, seed weight and seed yield during both experimental years. However non-significant influence of nitrogen levels was observed for number of pods and branched per plant. Highest level of nitrogen $\left(45 \mathrm{~kg} \mathrm{~N} \mathrm{ha}^{-1}\right)$ produced tallest chickpea plants. Although application of 
nitrogen at $30 \mathrm{~kg} \mathrm{ha}^{-1}$ produced maximum values of number of seed per pod, number of pods per plant, 100-seed weight and seed yield, however, these were statistically at par with the values produced at nitrogen rate of $45 \mathrm{~kg} \mathrm{ha}^{-1}$ during both experimental years. These results suggest that nitrogen fertilizer application at $30 \mathrm{~kg} \mathrm{ha}^{-1}$ as starter can be helpful in improving growth and yield of chickpea under agroclimatic conditions of Dokri.

\section{Authors' contributions}

Envisioned the project and designed the experiment: JS Dar \& MIA Rehmani, Performed the experiment: JS Dar, Pushpa \& ZA Abbassi, Performed statistical analysis: MIA Rehmani, JS Dar, Pushpa \& AG Magsi, Wrote and edited the paper: MIA Rehmani, JS Dar, Pushpa \& AG Magsi.

\section{References}

1. Gupta P (1988). Nutritive value of pulses. In: Pulse Crop. Baldev. S., Rawanujam and H. K. Jain (eds.). Oxford IBH Publishing Co. Pvt. Ltd. New Dehli pp 561-601.

2. Wood JA \& Grusak MA (2007). Nutritional value of chickpea. In Yadav, SS, Redden, RJ, Checn W \& Sharma B (ed) Chickpea breeding and management. CAB International.

3. ACA (2004). Agriculture crops: Alternatives chickpea. Alternative crop species Eds. RS Jessop, RL Wright pp 27-38.

4. Berger JD \& Turner NC (2007). The ecology of chickpea. InS.S. Yadav, R.J. Redden, W. Checn and B. Sharma (ed) Chickpea breeding and management. CAB International

5. Egamberdieva D, Shurigin V, Gopalakrishnan S \& Sharma R (2014). Growth and Symbiotic Performance of Chickpea (Cicer arietinum) cultivars under saline soil conditions. J Biol Chem Res 31(1):333-341.
6. Boukar O, Fatokun CA, Roberts PA, Abberton M, Huynh BL, Close TJ, Kyei-Boahen S, Higgins TJV \& Ehlers JD (2015). Cowpea. In: De Ron, A.M. (Ed.), Grain Legumes. Springer New York pp 219-250.

7. Chaludhury KA (1970). saraswatks Hason sn and csourrj 400 - 3500 years old barley, rye and pulses from Stranjikhera Scicu 37: 531 - 533.

8. FAO (2012) FAOSTAT. Food and Agriculture Organization of the United Nations.

9. McNeil D, Ahmad F, Abbo S \& Bahl PN (2007). Genetics and cytogenetics. Chickpea breeding and management (Yadav SS, Redden R, Chen $\mathrm{W}$ and Sharma B, eds.). Oxfordshire, $U K$ : $C A B$ International Publishing 321-353.

10. Anonymous (2015). Agric. Statistics of Pakistan. Govt. of Pakistan, Ministry of Food, Agri. and Livestock. Food, Agric. and Livestock division (Economic wing) Islamabad.

11. FAO (2010) FAOSTAT. Food and Agriculture Organization of the United Nations.

12. Saxena NP, Saxena MC, Johansen C, Virmani SM \& Harris H (1996). Future research priorities for chickpea in WANA and SAT. In: Saxena, N.P., Saxena, M.C., Johansen, C., Virmani, S.M., Harris, H. (Eds.), Adaptation of Chickpea in the West Asia and North Africa Region. ICARDA, Aleppo, Syria 257-263.

13. Ali M \& Kumar S (2009). Major technology advances in pulses. J Food Legumes 23: 169-185.

14. Akhtar LH, Minhas R, Bukahri MS \& Shah SAS (2015). Genetic Analysis of Some Quantitative Traits in Cluster Bean (Cyamopsis tetragonoloba L.). J Environ Agric Sci 4: 48-51.

15. Ahmad N, Davide JGD \& Aleem MTS (1998). Fertility status of soil in dry 
land areas of Pakistan. Proc. Int. Seminar on Dry Land Agriculture of Pakistan, November 6-8.

16. Ali AB, Altayeb OA, Alhadi $M$ \& Shuang-En Y (2014). Effect of different levels nitrogen and phosphorus fertilization on yield and chemical composition hybrid sunflower grown under irrigated condition. J Environ Agric Sci 1: 7.

17. Liu K, Li Y, Hu H, Zhou L, Xiao X \& Yu P (2015). Estimating rice yield based on normalized difference vegetation index at heading stage of different nitrogen application rates in southeast of China. J Environ Agric Sci 2: 13.

18. Caliskan S, Ozkaya I, Caliskan ME \& Arslan M (2008). The effect of nitrogen and iron fertilization on growth, yield and fertilizer use efficiency of soybean in Mediterranean type soil. Field Crops Res 108: 126132.

19. Salvagiotti F, Cassman KG, Specht JE, Walters DT, Weiss A \& Dobermann A (2008). Nitrogen uptake, fixation and response to $\mathrm{N}$ in soybeans: $\mathrm{A}$ review. Field Crops Res 108: 1-13.

20. Ahmad N \& Rashid M (2003). Fertilizer and their use in Pakistan, Govt. of Pakistan, National Fertilzier Development Centre pp 41-45.

21. Erman M, Demir S, Ocak E, Tufenkci S, Oguz F \& Akkopru A (2011). Effects of Rhizobium, arbuscular mycorrhiza and whey applications on some properties in chickpea (Cicer arietinum L.) under irrigated and rainfed conditions 1-Yield, yield components, nodulation and AMF colonization. Field Crops Research 122(1): 14-24.

22. Saeed M, Akram HM, Iqbal MS, Yar A \& Ali A (2004). Impact of fertilizer on the seed yield of chickpea. Int J Agric Biol 6(1):108- 109.

23. Sharar MS, Ayub M, Chaudhry MA \& Nadeem M (2000). Effect of NP application and inoculation on the growth and yield of gram. Pakistan $J$ Agri Sci 37(3-4): 155-157.

24. Walley FL, Kyei-Boahen S, Hnatowich G \& Stevenson C (2005). Nitrogen and phosphorus fertility management for desi and kabuli chickpea. Can. J Plant Sci 85: 73-79.

25. Li L, Yang T, Redden R, He W \& Zong $X$ (2016). Soil Fertility Map for Food Legumes Production Areas in China. Scientific reports 6 .

26. Kantar F, Hafeez FY, Shivakumar BG, Sundaram SP, Tejera NA, Aslam A, Bano A \& Raja P (2007). Chickpea: Rhizobium management and nitrogen fixation. In Chickpea Breeding and Management. Ed: S.S. Yadav. $C A B$ International pp 179-185

27. Walley FL, Clayton GW, Miller PR, Carr PM \& Lafond GP (2006). Nitrogen economy of pulse crop production in the Northern Great Plains. Agron J 99(6)1710-1718.

28. Gan YT, Warkentin TD, Bing DJ, Stevenson FC \& McDonald CL (2010). Chickpea water use efficiency in relation to cropping system, cultivar, soil nitrogen and Rhizobial inoculation in semiarid environments. Agric Water Manag 97(9): 1375-1381.

29. Ahlawat IPS, Gangaih B \& Zahid MA (2007). Nutrient management in chickpea. In Chickpea Breeding and Management. Ed: S.S. Yadav. $C A B$ International pp 214.

30. Fareed RD \& Scott DE (1986). MSTATC. Crop and Soil Science Department, Michigan State University, Michigan, USA.

31. Namvar A, Sharifi RS \& Khanda $T$ (2011). Growth analysis and yield of 
chickpea (Cicer arietinum L.) in relation to organic and inorganic nitrogen fertilization. Ekologija 57(3): 97-108.

32. El-Hadi EA \& El-Sheikh EAE (1999) Effect of Rhizobial inoculation and nitrogen fertilization on yield and protein content of six chickpea (Cicer arietinum L.) cultivars in marginal soils under irrigation. Nut Cycling Agroecosystems 54: 57-63.

33. Singh J, Bajaj JC \& Pathak H (2005) Quantitative estimation of fertilizer requirement for maize and chickpea in the alluvial soils of the Indo-Gangetic plains. J Indian Soc Soil Sci 53: 101106.

34. Amany AB (2007). Effect of plant density and urea foliar application on yield and yield components of chickpea (Cicer arietinum L.). Res $J$ Agric Biol Sci 3 (4): 220-223
35. Bahavar N, Ebadi A, Tobeh A \& Jamaati-E-Somarin S (2009). Effects of mineral nitrogen on water use efficiency of chickpea (Cicer arietinum L.) under water deficit condition. Research Journal of Environmental Sciences 3(3): 332-338.

36. Abdulla AR (2013). Growth and yield response of chickpea (Cicer arietinum L.) to different rates of nitrogen and potassium. Int J Agric and Crop Sci 517.

37. El Habbash SF, Mohamed MH, Abd ElLateef EM, Mekki BB \& Ibrahim ME (2013). Effect of combined zinc and nitrogen on yield, chemical constituents and nitrogen use efficiency of some chickpea cultivars under sandy soil conditions. WJ Agri Sci 9(4): 354-360. 